\title{
Assessing social acceptability of management options for harmonising irrigation with environmental concerns: A pilot study from the Murrumbidgee Valley, Australia\#
}

\author{
Catherine Allan ${ }^{1,2 *}$, Shahbaz Khan ${ }^{1,2}$ and Brian Davidson ${ }^{2,3}$ \\ 1 Environmental Sociology and Planning, School of Environmental Sciences, Institute for Land, Water and Society, \\ Charles Sturt University, PO Box 789, Albury NSW 2640 \\ ${ }^{2}$ Co-operative Research Centre for Irrigation Futures \\ ${ }^{3}$ Institute Of Land And Food Resources, University of Melbourne, Parkville, Victoria
}

\begin{abstract}
The flows in regulated rivers are strongly dependent on water demand by downstream water users. In irrigated catchments the river flow regimes are deliberately distorted to cater for crop demand, with significant deleterious ecological impacts. A number of opportunities exist to manipulate irrigation demand and supply to provide more natural seasonality of flows and optimise the social, environmental and economic outcomes from water use in a catchment. Possible options to achieve this goal include improved cropping mix incentives, groundwater - surface water substitution, intra and inter-seasonal water trading and harmonisation of on- and off-farm storage, distribution, application and drainage infrastructure with environmental outcomes. Each of these options will impact in some way on irrigation and wider communities. In this paper 'community' involvement in setting irrigation research agendas and evaluating water management options in the Murrumbidgee Valley, Australia is explored. A brief assessment of social acceptability, combined with hydrological and economic models, was found to be an effective approach for scoping different irrigation demand management options to improve seasonality of flows. In this study the value of articulating assessment criteria when dealing with new and potentially disruptive options for the management of irrigation demand in a catchment context is demonstrated.
\end{abstract}

Keywords: social acceptability, system harmonisation, conjunctive management of surface and groundwater, seasonality of flows, environmental management

\section{Introduction}

Local and community involvement in applied research is becoming increasingly valued by scientists and policy makers because it provides a source of new information and knowledge for defining and addressing issues (Bosch et al., 2003; Khan, 2004). In addition, engagement of a variety of stakeholders at all levels of learning and innovation development increases the relevance and immediate applicability of research outcomes (Burroughs, 1999; Allan and Curtis, 2002). When a specific research goal matches that of an impacted community, local involvement in the research process may be willing and harmonious. For example, much of the irrigation research undertaken to increase productivity and profits is done with the support, and even at the behest, of individual irrigators and their communities. However, reactions to, and involvement with, research aimed at achieving catchment-wide environmental objectives is less straightforward. Environmentally driven research may be perceived to be at the expense of the short term interests of some individual irrigators or their communities. Understanding the acceptability

Revised paper. Originally presented at the symposium 'HELP in Action: Local Solutions to Global Water Problems - Lessons from the South' which was held at the Emperor's Palace, Johannesburg, South Africa from 4 to 9 November 2007.

* To whom all correspondence should be addressed.

+612 519781; fax: +61 2 519897;

e-mail: callan@csu.edu.au (or otherwise) of environmentally focused irrigation innovations is a way to promote efficiency and efficacy of research efforts, and to begin the community involvement which will aid in adoption of the innovations. This paper presents results from a pilot study which explored the social acceptability of environmentally focused irrigation management options in a systematic way. The lessons from this pilot may be useful for other researchers and implementation organisations attempting to balance human and environmental needs within irrigation areas.

\section{Background}

The Murrumbidgee catchment covers an area of $73400 \mathrm{~km}^{2}$ of Australia's major 'food bowl', the Murray-Darling Basin (MDB) (see Fig. 1). The Murrumbidgee River runs $1600 \mathrm{~km}$ from its source in the Snowy Mountains to its junction with the Murray River. It is characterised by large irrigated agricultural and irrigated pastoral developments, including the Murrumbidgee and Coleambally Irrigation Areas. In an average year, such as 2000-01, the Murrumbidgee River conveys approximately 4300 MCM of water, of which about $65 \%$ is licensed for diversion for irrigation and other human uses. There are 14 major dams, 8 large weirs and over $10000 \mathrm{~km}$ of irrigation canals associated with the Murrumbidgee River (Khan et al., 2004).

The communities of the Murrumbidgee Valley have established successful and valuable enterprises based on the innovative use of water in agriculture, horticulture and the concomitant value-adding businesses that exist in association with these industries. There are several new intensive livestock and feedlot 


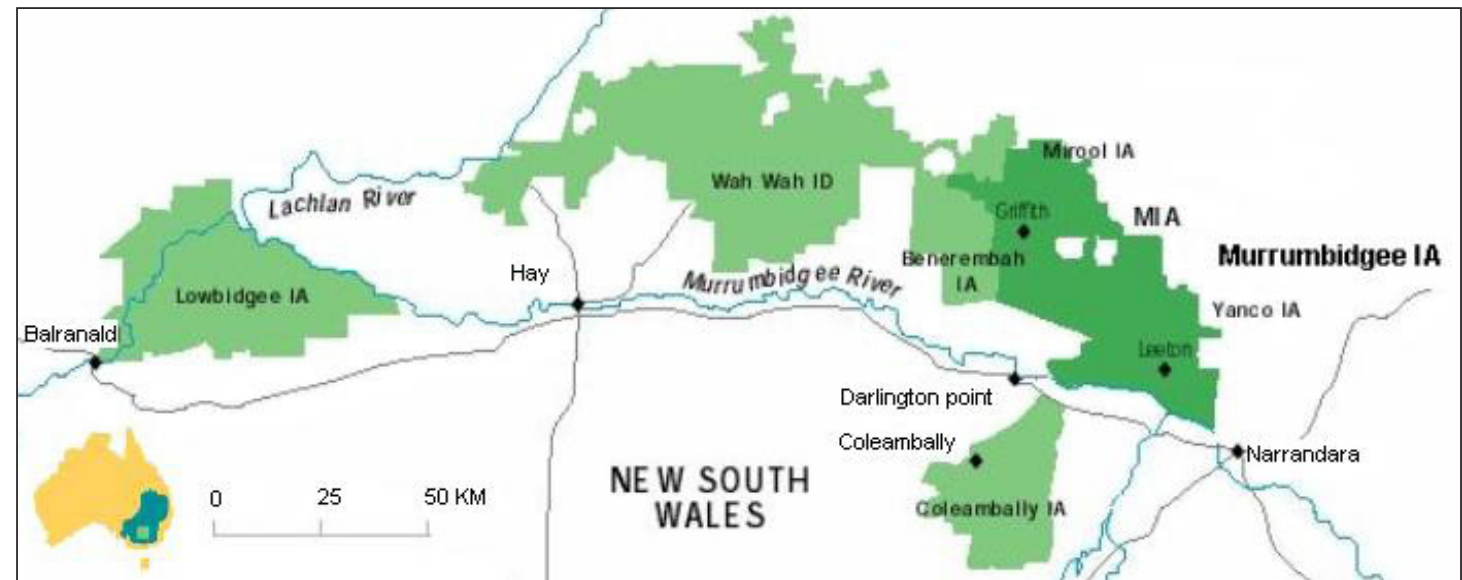

Figure 1

Location map of the Murrumbidgee River Valley

developments along the river, viticulture is expanding in selected areas, and the number of agricultural processing industries is increasing within the valley. There is competing demand for surface and groundwater use in agriculture, as well as for tourism and for environmentally focused purposes such as 'environmental flows' to maintain or enhance ecological processes.

The physical and ecological characteristics of the river systems within the MDB have been extensively modified through a range of interventions and the most significant are those associated with flow regulation (Davis and Hirji, 2003). Natural water flow regimes within the river have been considerably altered, in terms of rate, temporal variability, and volume over season. Along the Murrumbidgee and Murray Rivers the seasonality of flow has been inverted; the highest flows now occur in summer to meet the needs of irrigators and inland towns, with the lowest flows now in winter and spring, when the storages refill. Altered flow regimes have been identified as one of the drivers of declining riverine and wetland condition in south eastern Australia (Norris et al., 2001; Department of the Environment and Heritage, 2001; EPA Environmental Reporting, 2003). The inversion of flow regimes has had significant deleterious ecological impacts in the Murrumbidgee system through reduced frequency of inundation of wetlands and associated changes in riverine biomass (Page et al., 2005). It is logical to expect that a return to more natural flow regimes would lead to improved ecological outcomes.

The question is how can natural flow regimes be at least partially restored, without destroying the enterprises and communities that have developed in conjunction with irrigation? Traditional approaches for securing environmental flows aim to recover a volume of water by either:

- Reducing allocations to irrigators without compensation

- Buying it and providing compensation to farmers directly or through purchases on the open market

- 'Saving' it, through improving infrastructure to reduce evaporation from supply systems.

Each of these approaches involve high social and political costs for managing environmental flows, but none of them adequately address the challenges associated with the changes that have altered the seasonality of river flows.

An alternate approach for achieving better environmental outcome in rivers may be to improve the seasonality of flows by using different irrigation demand management options. These options would be designed to reduce peak summer demand for irrigation water, in conjunction with changes to farm and district enterprises. With careful mixing these options could maintain or increase farm viability while spreading demand over summer and winter periods. A Cooperative Research Centre for Irrigation Futures scoping project, entitled Improved Seasonality of Flows and System Harmonisation (ISFSH), was designed to test if a seasonality-based demand management approach is feasible for the Murrumbidgee area. Irrigation in southern Australia has operated in a development and increased productivity paradigm since Alfred Deakin spearheaded its development in the mid 1880s (Proust, 2003). A seasonality of flow approach to water management is a challenge to that paradigm and could be seen to be a direct threat to individual irrigators and irrigation companies. Thus, of interest within the ISFSH project was how best to involve members of the irrigation community in the process of considering possible significant changes, even while those possible changes remained unformed and potentially threatening.

Agricultural and rural development practise around the world been strongly influenced by the 'transfer of technology' approach to change and innovation. This approach focuses on the development of a 'product' - such a new piece of equipment, or a set of practices - by scientists and technologists, who then transfer their understanding of the innovation to the practitioners in the field (Ison, 2000). This approach works particularly well for 'products' developed specifically to improve short term farm profitability or productivity. Because the transference of ideas in this model is anticipated as being from scientific or technical experts to practitioners the main role for other stakeholders, such as farmers, is that of passive receivers. The assumption underpinning the transfer of technology approach is that the innovation is good for the recipient stakeholders, so if uptake is slow it is because of 'barriers' to adoption. In the transfer of technology approach much effort is directed to identifying and addressing these barriers to the uptake of the innovation; in other words, the innovative 'product' remains constant, while stakeholder concerns are 'managed' to encourage uptake. While the transfer of technology approach is a well established model for understanding agricultural extension, there is growing recognition of the importance of understanding the social context into which the innovation is being introduced. Introducing context requires some assessment and understanding of the social acceptability of the innovative 'product' or proposed change(s). Assessing social acceptability requires a less narrow understanding of information and knowledge sharing processes because the nature of the innovation is considered to be negotiable in response to societal context. A focus on social acceptability is more conducive to stakeholder participation in uptake and redesign (Steyaert and Ollivier, 2007). When considering the introduction of difficult and or disruptive innovations into communities that rely on production from natural resources, a focus on social acceptability, 
rather than on transfer of technology, is likely to be more useful than ToT. Social acceptability theory emphasises the importance of understanding how judgements about whether to accept and adopt are made. Making judgements involves more than just reviewing and weighing substantive information; judgements evolve from a complex suite of factors including individual and cultural context, knowledge and understanding of alternatives and consequences and trust in decision makers. The idea of judgement also implies comparative assessment of options (Stankey and Shindler, 2006).

The ISFSH scoping project aimed to develop new irrigation system management options, and it was considered important to develop a systematic approach for making some preliminary judgements during the option development phase itself. However, the appropriate form of stakeholder engagement was problematic. As suits a scoping project the options would be articulated as broad, imprecise ideas. Attempting to engage a wide range of stakeholders at this highly speculative stage could have the potential to cause anxiety and antagonism within the stakeholder communities. However, stakeholder involvement in the further selection and development of the options could be expected to result in more immediately relevant and acceptable options for their community. The dilemma about when and how to best to involve stakeholders was resolved in this project by aiming the initial engagement at the irrigation industry level, rather than with large cohorts of individual irrigators. The engagement involved a meeting of these stakeholders in April 2005, with a second meeting in March 2006.

\section{Gauging the social acceptability of different options - Phase 1}

The first meeting was held in a large irrigation town in the Murrumbidgee Valley. Invited participants included local water distribution company managerial staff, state agency employees, representatives from the Commonwealth Scientific and Industrial Research Organisation (CSIRO) and the Murray-Darling Basin Commission, university irrigation researchers, plus two locally prominent irrigation farmers. The workshop participants mostly represented those with a primary interest in irrigated farming productivity and profitability, although it was recognised that people may hold many values (for example, being involved with irrigated farming does not preclude a person from having environmental concerns). The specific aims of the first meeting were to:

1 Develop draft criteria for assessing water demand management projects/ideas

2 Share project ideas between the research team and other (i.e. community) experts

3 Assess the proposed ideas against the draft criteria developed in Item 1.

As noted above, the options developed in the ISFSH pilot project involve different ways of thinking about available and potential water resources, the nature of irrigation farming in Australia and the relationships between individual farms and the broader environment. To 'gauge' the social acceptability of these options it was necessary to follow a systematic and transparent process to avoid unreflective or reflex reactions to new ideas, and to reduce opportunities for manipulation. The process used at the first meeting centred on articulating criteria against which any irrigation demand management options could or should be evaluated. A workshop approach as described by Spencer (1989) was used to enable the meeting participants to develop these (draft) assessment criteria together. The workshop involved uncritical generation of ideas from all participants ('brainstorming') in response to the question 'What criteria would you use to judge the effectiveness of a water management project?' All the participants then assisted in collecting the responses into categories, or sets and labelling those sets with a heading that reflected all of the individual responses within them. This resulted in 11 criteria by which participants felt they could compare and judge options for any proposed water project, including those aimed at improved seasonality of flows in the Murrumbidgee River. The 11 criteria articulated were:

- Improved water use efficiency

- Demonstrated impacts on water availability

- Sound stakeholder processes

- Feasibility

- Significance

- Risk reduction

- Equity/fairness

- Identify costs/ cost minimisation

- Economic benefits

- Social benefits

- Environmental benefits.

Once these draft criteria were developed by the participants the second aim was addressed by providing some information about past and current ground and surface flows in the district before asking participants to share possible options for harmonising irrigation demand with river flow regimes. Five of the options presented were developed as part of the ISHSF project and two were added by other workshop participants. The options are summarised in Fig. 2.

A blank matrix was formed with the seven options on one axis, and the previously articulated criteria on the other axis. Five

\section{ISHSF options}

\section{- Cropping mix or pattern change}

Different mixes of summer and winter crops from those currently grown would result in spreading of irrigation demand, improving seasonality of flow and irrigator profitability, given the same annual volume of water.

- Balancing en-route storage

This would involve arranging small water storage facilities closer to the irrigated areas than the current large reservoirs, thus changing dam release patterns

\section{- Water trading}

Use economic trading with the primary objective of improving seasonality of flow management.

- Explore conjunctive use of groundwater and surface water This would involve large scale storage of water in existing aquifers, to even out or harmonise surface flows. It has the added advantage of providing some management for saline groundwater.

- Selling water as a service

Which involves selling the 'moisture needed', rather than fixed allocations of water (see Davidson, 2004).

\section{Added options}

- An environmental barrage barge This engineered option would involve a moveable barrage to create local floods where and when they are needed for environmental replenishment of river features, such as billabongs.

- Reducing evaporation from lakes and wetlands, which involves managing or capturing the water lost from evaporation from the current large storages, and possibly smaller en-route storages as well.

\section{Figure 2}

The system harmonisation options presented at the first meeting 


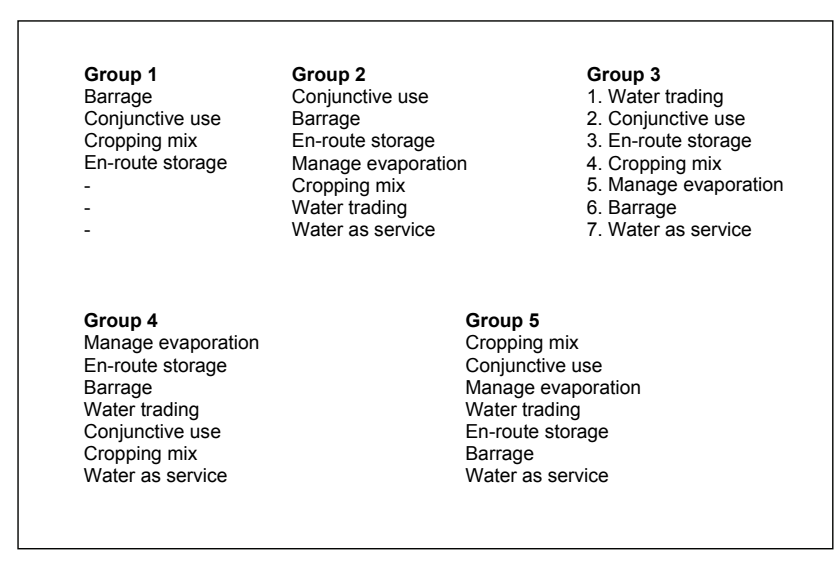

Figure 3

The seven options for enhancing seasonality of flow and system harmonisation, ranked by the 5 groups of irrigation community members at the first community meeting, April 2005.

groups were then formed from within the workshop participants to assess the options. Each group was asked to assign up to five points to each box in the matrix, with five points being totally acceptable, and 0 points being totally unacceptable. Adding the criteria scores provides a ranking of the projects (although one group chose to go straight to ranking the projects). The ranking from highest score to lowest by each group is shown in Fig. 3.

Each group placed a different option at the top of their list; however there were some patterns worth noting. The conjunctive use of water option was ranked 1 or 2 by four of the groups. Thus, it could be concluded that it had reasonably comprehensive support or at least participants had some interest in the approach. The Barrage, various forms of en-route storage and managing evaporation scored either very high or very low, while the cropping mix and water trading ideas were in the median range for most groups. Selling water as a service was ranked either last, or not considered, by all groups.

Clearly ranking the ideas in an afternoon workshop session was not rigorous, nor definitive, as each criterion is given equal weight. Given this, and the non-random selection of participants it is impossible (as well as unwise) to make statistical generalisations about the results of the first meeting. However, it can be concluded from this initial meeting that it is possible to approach new and potentially threatening ideas through a systematic process that provides some direction for future research. Some understanding was developed about the immediate social acceptability or otherwise of each option. The value of the systematic process used was that, along with this broad estimation of acceptability, there was some articulation and investigation of reasons behind the judgements. This allows for a process of informed improvements to be undertaken.

The process of articulating assessment criteria not only allowed considered judgements about the acceptability of proposals, it also indicated specific areas where project ideas may need to change to become more socially acceptable. The conjunctive use of water option scored less well against the criteria of stakeholder processes, cost minimisation, social benefits and equity than the other criteria, suggesting that this project could become more acceptable by addressing these issues. Financial incentives, or a greater emphasis on involving stakeholders and developing equitable sharing arrangements, or compensation may be required to make this option more acceptable. On the other hand the Barrage project idea scored poorly against efficiency, flexibility, significance, suggesting a niche role rather than a large scale option for system harmonisation. The cropping mix project idea scored poorly in many areas, but particularly against the criteria of risk reduction, equity, water use efficiency and stakeholder processes. If the cropping mix option is to be pursued much more work with individual and community water users is required to manage risk, ensure equity and to ensure that there are some water use benefits. Possibly financial or other incentives would be required to improve the score in these areas.

After the first workshop physical and economic modelling in the ISFSH project focused on refining and detailing some of the seasonality of flow options. The main objective of the hydrological modelling was to quantify water saving and possible reduction in peak irrigation demand, both at farm and system-level, under different soil types. The economic modelling included considering alternative strategies for water re-allocation, distribution of costs and benefits and policy decision choices. The policy interventions significantly facilitate and influence the process that produces the desired objectives.

\section{Gauging the social acceptability of different options - Phase 2}

By March 2006 the options discussed at the initial meeting had been developed in sufficient detail to re-present to the community participants. A second meeting, with the same invitation list, was held in another Murrumbidgee irrigation town. For various reasons, fewer people were able to attend the second workshop. Despite this, a useful discussion about the options ensued. The options under consideration at the second meeting were similar to those discussed at the first meeting, and included a baseline (i.e. current) approach, market based surface water demand reduction, managed accessible aquifer recharge/ conjunctive water use, spreading water demand with improved cropping mixes, increased system and/or end use efficiencies and en-route storages. The options were presented with information about the impacts of each under a $10 \%$ (Table 1) and a $20 \%$ (Table 2) market based reduction in water demand.

Again the approach used to discuss the options involved a facilitated workshop, this time focused on whether each option was worth pursuing, and what issues were important for further consideration with each option.

Workshops participants considered each of the options as worth pursuing, although it was noted that the increased system and end use efficiency options were already being explored well in other projects. The option of spreading water demand with improved cropping mixes again received a mixed reception by community participants; some participants thought it was a not worth pursuing, while others thought that, while it had some potential, it was a lower priority for research than the other options.

The major issues discussed in relation to these options involved structural constraints, equity, ecological improvements and public perceptions. The option centred on managed accessible aquifer recharge was anticipated to have good environmental impacts, but participants were unsure how the costs and benefits could be fairly distributed among the irrigation and the wider communities. It was also suggested that not being able to see the stored water might reduce the desirability of this option. On the other hand, the issues for en-route storages included doubt over the environmental benefits, but acknowledgement that it would be a popular option for many stakeholders who would benefit from the efficiency of delivery without having to pay direct costs for the increase. The issues related to the improved cropping mix 


\begin{tabular}{|l|c|c|c|c|c|c|c|c|}
\hline \multicolumn{7}{|c|}{$\begin{array}{l}\text { TABLE 1 } \\
\text { manparison of water use and income of baseline conditions with proposed demand }\end{array}$} \\
\hline Scenarios & $\begin{array}{c}\text { Gross } \\
\text { return } \\
\text { (\$M) }\end{array}$ & $\begin{array}{c}\text { Benefit } \\
\text { or loss to } \\
\text { agriculture } \\
\text { (\$M) }\end{array}$ & $\begin{array}{c}\text { Construc- } \\
\text { tion costs } \\
\text { (\$M) }\end{array}$ & $\begin{array}{c}\text { Other cost } \\
\text { (\$M) }\end{array}$ & $\begin{array}{c}\text { Surface } \\
\text { water use } \\
\text { (GL) }\end{array}$ & $\begin{array}{c}\text { Ground- } \\
\text { water use } \\
\text { (GL) }\end{array}$ & $\begin{array}{c}\text { Total } \\
\text { water use } \\
\text { (GL) }\end{array}$ & $\begin{array}{c}\text { Available } \\
\text { water } \\
\text { (GL) }\end{array}$ \\
\hline Baseline & 292.30 & 0.00 & 0.00 & 0.00 & 1399.26 & 0.00 & 1399.26 & 0.00 \\
\hline $\begin{array}{l}\text { Voluntary reduction in surface } \\
\text { water supply }\end{array}$ & 276.16 & -16.14 & 0.00 & 0.00 & 1284.81 & 0.00 & 1284.81 & 114.45 \\
\hline Groundwater extraction only & 291.04 & -1.26 & 0.00 & 0.00 & 1284.81 & 114.45 & 1399.26 & 114.45 \\
\hline $\begin{array}{l}\text { Groundwater infiltration + } \\
\text { extraction (ASR development) }\end{array}$ & 287.78 & -4.49 & 0.00 & 0.00 & 1284.81 & 114.45 & 1399.26 & 114.45 \\
\hline $\begin{array}{l}\text { Spreading water demand with } \\
\text { improved cropping mix }\end{array}$ & 297.43 & 5.49 & 0.00 & 0.00 & 1282.07 & 0.00 & 1282.07 & 115.74 \\
\hline Increase system efficiency & 292.30 & 0.00 & 18.72 & 1.18 & 1399.26 & 0.00 & 1399.26 & 114.45 \\
\hline Increase end use efficiency & 284.41 & -7.89 & 0.00 & 0.00 & 1216.77 & 0.00 & 1216.77 & 182.50 \\
\hline $\begin{array}{l}\text { Substitute water use (en-route } \\
\text { storages) }\end{array}$ & 292.30 & 0.00 & 4.58 & 2.00 & 1399.26 & 0.00 & 1399.26 & 119.00 \\
\hline
\end{tabular}

*O\&M cost, etc.

\begin{tabular}{|c|c|c|c|c|c|c|c|c|}
\hline \multicolumn{9}{|c|}{$\begin{array}{c}\text { TABLE } 2 \\
\begin{array}{c}\text { Comparison of water use and income of baseline conditions with proposed demand } \\
\text { options at system level after a reduction of surface water demand by } 20 \%\end{array}\end{array}$} \\
\hline Scenarios & $\begin{array}{l}\text { Gross } \\
\text { return } \\
(\$ M)\end{array}$ & $\begin{array}{l}\text { Benefit } \\
\text { or loss to } \\
\text { agriculture } \\
\text { (\$M) }\end{array}$ & $\begin{array}{l}\text { Construc- } \\
\text { tion costs } \\
\quad(\$ M)\end{array}$ & $\begin{array}{l}\text { Other cost* } \\
\text { (\$M) }\end{array}$ & $\begin{array}{l}\text { Surface } \\
\text { water use } \\
\text { (GL) }\end{array}$ & $\begin{array}{l}\text { Groundwa- } \\
\text { ter use } \\
\text { (GL) }\end{array}$ & $\begin{array}{l}\text { Total water } \\
\text { use } \\
\text { (GL) }\end{array}$ & $\begin{array}{c}\text { Available } \\
\text { water } \\
\text { (GL) }\end{array}$ \\
\hline Baseline & 292.30 & 0.00 & 0.00 & 0.00 & 1399.26 & 0.00 & 1399.26 & 0.00 \\
\hline $\begin{array}{l}\text { Voluntary reduction in sur- } \\
\text { face water supply }\end{array}$ & 255.47 & -36.82 & 0.00 & 0.00 & 1183.03 & 0.00 & 1183.03 & 216.24 \\
\hline Groundwater extraction only & 289.07 & -3.23 & 0.00 & 0.00 & 1183.03 & 216.24 & 1399.26 & 216.24 \\
\hline $\begin{array}{l}\text { Groundwater infiltration+ } \\
\text { extraction (ASR development) }\end{array}$ & 283.29 & -8.96 & 0.00 & 0.00 & 1183.03 & 216.24 & 1399.26 & 216.24 \\
\hline $\begin{array}{l}\text { Spreading water demand with } \\
\text { improved cropping mix }\end{array}$ & 287.16 & -4.79 & 0.00 & 0.00 & 1181.77 & 0.0 & 1181.77 & 216.04 \\
\hline Increase system efficiency & 292.30 & 0.00 & 35.68 & 7.35 & 1399.26 & 0.00 & 1399.26 & 216.24 \\
\hline Increase end use efficiency & 280.69 & -11.61 & 0.00 & 0.00 & 1155.92 & 0.00 & 1155.92 & 243.35 \\
\hline $\begin{array}{l}\text { Substitute water use (en-route } \\
\text { storages) }\end{array}$ & 292.30 & 0.00 & 7.02 & 2.00 & 1399.26 & 0.00 & 1399.26 & 203.00 \\
\hline
\end{tabular}

*O\&M cost, etc.

option include environmental impacts on adjacent wetlands and increased financial and lifestyle costs for irrigation farmers. The market based option was considered to face large institutional constraints, as well as having high transaction costs. Participants also felt that there was no guarantee that water savings would result in improved environmental outcomes.

\section{Discussion}

It was evident from the two workshops that some options for improving seasonality of flows in rivers through irrigation demand management and harmonising irrigation systems with the environment were more acceptable to this group of stakeholder participants than other options. Further, it could be concluded that the level of acceptability influenced what participants considered as worthwhile research to pursue. The most acceptable options for this group were those that involved changes to the delivery of water to the irrigation district and/or individual properties. The development and co-ordination of enroute storages and various processes for achieving conjunctive use of ground and surface water were seen to have the potential to produce some environmental enhancement with minimal disruption to the irrigation community. Options which had more direct and potentially negative impacts on individual farmers, such as spreading water demand with improved cropping mix, were not as acceptable to the meeting participants. These findings provide direction for future research and trialling of system harmonisation options.

The first workshop demonstrated the value of articulating assessment criteria when dealing with new and potentially disruptive options for management of irrigation demand. The process of articulating water management assessment criteria provided an opportunity for people to share their expertise, experience and anxieties, as well as to contribute to the 
development of a research project in their area. The assessment criteria developed at the first meeting were only approximations; a refinement of those criteria through meetings with different community members will be necessary for them to become a truly useful tool. However, even as a rough tool the areas of the different options that requires further work to make them more acceptable to the irrigation community are clearly articulated.

It should be noted that the value of developing assessment criteria was reduced by working within the constraints of a scoping project. Only two meetings were possible, and only a few participants were able to attend the meetings. However, while the draft outcomes are limited, there has been some advance in developing trust between the research team and the irrigation community. As a technique for future development of projects within initially unenthusiastic communities, this workshop based systematic approach to articulating criteria and then making judgements shows some promise.

\section{References}

ALLAN C and CURTIS A (2002) Participatory rural appraisal: Using it to understand rural communities. Nat. Resour. Manage. 5 (1) 28-34.

BOSCH OJH, ROSS AH and BEETON RJS (2003) Integrating science and management through collaborative learning and better information management. Syst. Res. Behaviour Sci. 20 (2) 107-118.

BURROUGHS R (1999) When stakeholders choose: Process, knowledge, and motivation in water quality decisions. Soc. Natural Resour. 12 797-809.

DAVIDSON B (2004) The Problems of Analysing Markets for Irrigation Water. Annual Conference of the Australian Agricultural Economics and Resource Society, Melbourne, Australia.

DAVIS R and HIRJI R (eds.) (2003) Environmental Flows: Case Studies. Water Resources and Environment Technical Notes. The International Bank for Reconstruction and Development/The World Bank. Washington, D.C. USA.
DEPARTMENT OF THE ENVIRONMENT AND HERITAGE (2001) Australian State of the Environment (2001) Thematic findings: Inland waters. CSIRO Publishing, Parkes, ACT. Available at http://www.deh.gov.soe/2001/water.html\#surfacewaterresources (Accessed 1 August 2006).

EPA ENVIRONMENTAL REPORTING (2003) NSW State of the Environment 2003, EPA 2003/89. Department of Environment and Conservation, Sydney.

ISON RL (2000) Technology: Transforming grazier experience. In: Ison RL and DB (eds.) Agricultural Extension and Rural Development: Breaking out of Traditions. Cambridge: Cambridge University Press.

KHAN S (2004) Integrating hydrology with environment, livelihood and policy issues - the Murrumbidgee Model. Special Volume on Hydrology for the Environment Life and Policy. Water Resour. Dev. 20 (3) $415-429$.

KHAN S, AKBAR S, RANA T, ABBAS A, ROBINSON D, DASSANAYKE D, HIRSI I, BLACKWELL J, XEVI E and CARMICHAEL A (2004) Hydrologic Economic Ranking of Water Saving Options in Murrumbidgee Valley: Water Efficiency Feasibility Project. Consultancy Report to Pratt Water Group, Melbourne, Australia.

NORRIS RH, LISTON P, DAVIES N, COYSH J, DYER F, LINKE S, PROSSER I and YOUNG B (2001) Snapshot of the Murray-Darling Basin river condition, CSIRO, CRC for Freshwater Ecology and the National Land and Water Audit, Canberra.

PAGE K, READ A, FRAZIER P and MOUNT N (2005) The effect of altered flow regime on the frequency and duration of bankfull discharge - Murrumbidgee River, Australia. River Res. Appl. 21 (5) $567-578$.

PROUST K (2003) Ignoring the signals. Irrig. Drain. 52 (1) 39-49.

SPENCER LJ (1989) Winning through Participation. Kendall/Hunt Publishing Company, Dubuque.

STANKEY GH and SHINDLER BA (2006) Formation of social acceptability judgments and their implications for management of rare and little-known species. Conserv. Biol. 20 (1) 28-37.

STEYAERT P and OLLIVIER G (2007) The European water framework directive: How ecological assumptions frame technical and social change. Ecol. Soc. 12 (1) 25. [online] URL: http://www.ecologyandsociety.org/vol12/iss1/art25/ 